\title{
Importance of cone beam computed tomography in the diagnosis of root perforation:
}

\section{a case report}

\author{
Importância da tomografia computadorizada de feixe cônico no diagnóstico da perfuração \\ radicular: relato de caso
}

Importancia de la tomografía computarizada de haz cónico en el diagnóstico de perforación

radicular: reporte de un caso

\author{
Sandy Rabelo Lima \\ ORCID: https://orcid.org/0000-0003-0326-1460 \\ Universidade do Estado do Rio Grande do Norte, Brazil \\ E-mail: sandy_rabelo@hotmail.com \\ Denise Hélen Imaculada Pereira de Oliveira \\ ORCID: https://orcid.org/0000-0001-6020-2374 \\ Universidade Federal do Ceará, Brazil \\ E-mail: denisehelen2011@hotmail.com \\ Francisca Damares da Silva Mesquita \\ ORCID: https://orcid.org/0000-0001-7190-3408 \\ Universidade do Estado do Rio Grande do Norte, Brazil \\ E-mail: damares.smesquita@gmail.com \\ Eduardo José Guerra Seabra \\ ORCID: https://orcid.org/0000-0003-3166-6553 \\ Universidade do Estado do Rio Grande do Norte, Brazil \\ E-mail: egs1974@gmail.com \\ Patrícia Bittencourt Dutra dos Santos \\ ORCID: https://orcid.org/0000-0003-3308-6376 \\ Universidade do Estado do Rio Grande do Norte, Brazil \\ E-mail: pati_bittencourt@hotmail.com \\ Fernando José de Oliveira Nóbrega \\ ORCID: https://orcid.org/0000-0002-0121-0996 \\ Universidade do Estado do Rio Grande do Norte, Brazil \\ E-mail: nobrega.fernando@hotmail.com
}

\begin{abstract}
Endodontic perforations are defined as a iatrogenic mechanical communication between the root canal and supporting periodontal tissues. Dental imaging techniques are essential for satisfactory detection of these conditions. The purpose of this study was to describe the clinical case of a patient diagnosed with endo-periodontal cystic lesion by endodontic perforation by cone beam computed tomography (CBCT). A 67-year-old female patient who required oral rehabilitation treatment with an implant-supported denture in the posterior mandible was seen at the Dental Clinic of the State University of Rio Grande do Norte (UERN). Based on the data collected during clinical examination, complementary tests were requested for assessment of his overall dental condition. Periapical radiography revealed the presence of a lesion in the apex of tooth 22, which was associated with an endodontic lesion. CBCT showed a lateral lesion caused by root perforation suffered during prior endodontic treatment. After histopathological analysis, the diagnosis was a radicular cyst. This study highlights the importance of CBCT imaging for establishment of the correct diagnosis, treatment planning, and prevention of complications.
\end{abstract}

Keywords: X-ray computed tomography; Diagnostic imaging; Endodontics.

\section{Resumo}

As perfurações endodônticas são definidas como uma comunicação mecânica iatrogênica entre o canal radicular e os tecidos periodontais de suporte. As técnicas de imagem dentária são essenciais para a detecção satisfatória dessas condições. Assim, o objetivo deste estudo foi descrever o caso clínico de um paciente com diagnóstico de lesão cística endo-periodontal por perfuração endodôntica por tomografia computadorizada feixe cônico (TCFC). Paciente do sexo feminino, 67 anos, que necessitou de tratamento de reabilitação oral com prótese implantossuportada em região posterior de mandíbula, foi atendida na Clínica Odontológica da Universidade do Estado do Rio Grande do Norte (UERN). Com base nos dados coletados durante o exame clínico, foram solicitados exames complementares para avaliação do seu estado dentário geral. A radiografia periapical revelou a presença de lesão em ápice do dente 22, 
associada a lesão endodôntica. A TCFC mostrou lesão lateral causada por perfuração radicular sofrida durante o tratamento endodôntico prévio. Após análise histopatológica, o diagnóstico foi de cisto radicular. Este estudo destaca a importância da TCFC para o estabelecimento do diagnóstico correto, planejamento do tratamento e prevenção de complicações.

Palavras-chave: Tomografia computadorizada de raios-X; Diagnóstico por imagem; Endodontia.

\section{Resumen}

Las perforaciones endodónticas se definen como una comunicación mecánica iatrogénica entre el conducto radicular y los tejidos periodontales de soporte. Las técnicas de imágenes dentales son esenciales para la detección satisfactoria de estas condiciones. El objetivo de este studio fue descubrir el caso clínico de un paciente diagnosticado de lesion quística endoperiodontal por perforación endodóntica mediante tomografia computadorizada de rayos X (TCRX). Una paciente de 67 años que requirió tratamiento de rehabilitación oral con prótesis implantosoportada en la región posterior de la mandíbula, fue atendida en la Clínica Dental de la Universidad Estatal de Rio Grande do Norte (UERN). A partir de los datos recogidos durante el examen clínico, se solicitaron pruebas complementarias para evaluar su estado dental general. La radiografía periapical reveló la presencia de una lesión en el ápice del diente 22 , asociada a lesión endodóntica. La TCRX mostró una lesión lateral causada por la perforación de la raíz sufrida durante el tratamiento endodóntico previo. Tras el análisis histopatológico, el diagnóstico fue de quiste radicular. Este estudio destaca la importancia de TCRX para establecer el diagnóstico correcto, la planificación del tratamiento y la prevención de complicaciones.

Palabras clave: Tomografía computarizada de rayos X; Diagnóstico por imágenes; Endodoncia.

\section{Introduction}

Dentistry's principle is the maintenance of the tooth in order to preserve the balance of the stomatognathic apparatus. However, in some clinical situations such as endodontic perforations, which are difficult to diagnose and have a unfavorable prognosis, the best therapeutic option is often extraction of the tooth involved.

Endodontic perforations are defined as a pathological mechanical communication between the root canal and the periodontal tissue supporting the tooth (Tsesis \& Fuss, 2006). These perforations account for $10 \%$ of all accidents that occur during endodontic treatment and can be caused by factors such as caries, resorption, aberrant canal morphology, errors in access cavity preparation, and failure during chemical-mechanical preparation and intracanal pin placement caused by negligence, carelessness or inexperience of the professional (Alves, Gomes, Sayão \& Mourato, 2005).

Dental imaging methods have become essential for the detection of root alterations throughout all steps, assisting in the diagnosis, treatment planning and prevention of complications (Takeshita, Chicarelli \& Iwaki, 2015). However, despite the advances in imaging resources, the diagnosis of some root alterations, such as vertical root fracture, external root resorption and root perforation, can be extremely challenging, especially when specific clinical signs and symptoms are absent (Bernardes et al, 2009; Moudi et al, 2014). In this case, a more accurate method is necessary. Despite its widespread use, periapical radiography has limitations, for example providing two-dimensional images of three-dimensional structures, which can lead to misdiagnosis and consequent incorrect treatment (Scarfe, 2011). Thus, diagnostic accuracy is fundamental for the success of treatment.

Within this context, imaging science has witnessed advances in medical imaging over the past decades that were applied, with varying degrees of success, to different areas of Dentistry. These advanced imaging techniques are important by permitting imaging in different planes (Bueno et al, 2007), as well as the visualization of anatomical structures and pathologies in three dimensions with better resolution. In this respect, cone beam computed tomography (CBCT) is considered a highprecision technique (Baratto Filho et al, 2009).

In view of the above considerations, the objective of this study was to describe the clinical case of a patient in whom a endo-periodontal cystic lesion caused by endodontic perforation was diagnosed by CBCT. 


\section{Methodology}

A descriptive study was performed, the account type of case, which is the detailed description of patient diagnosis and treatment of disease (A.S. Pereira et al., 2018). The entire study was conducted based on the principles of ethics and bioethics, approved by resolution number 466 of December 12, 2012 of the National Health Council. The patient signed the Free and Informed Consent Term, in which the research objectives were clarified and privacy, confidentiality and anonymity are ensured.

\section{Case Report}

Patient M.L.C.M., a 67-year-old woman, was seen at the Dental Clinic of the State University of Rio Grande do Norte (UERN) for consultation about the placement of mandibular implants and subsequent prosthetic rehabilitation in the area of the premolars and lower molars. Clinical examination revealed mild gingival inflammation in the area adjacent to the metalceramic crowns of teeth 11 and 21 . The fixed bridges of teeth 14 to 17 and 23 to 27 , the unitary crowns of teeth $11,12,21,22$ and 34 , and the fixed bridge of teeth 44 to 47 exhibited color stability, marginal adaptation preparation/prosthetic restoration, and occlusal and masticatory performance (Figures 1 and 2).

Figure 1: Initial appearance of the clinical case. Observe the metal-ceramic crown of tooth 21 performed 10 years ago and its good color quality and marginal adaptation.

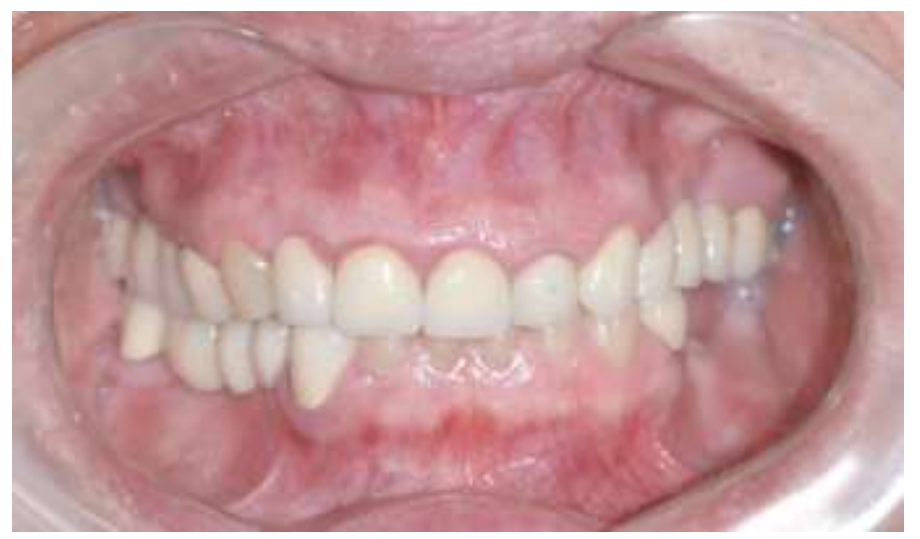

Source: Authors.

Figure 2. Note the absence of any clinical sign indicating periapical abnormalities.

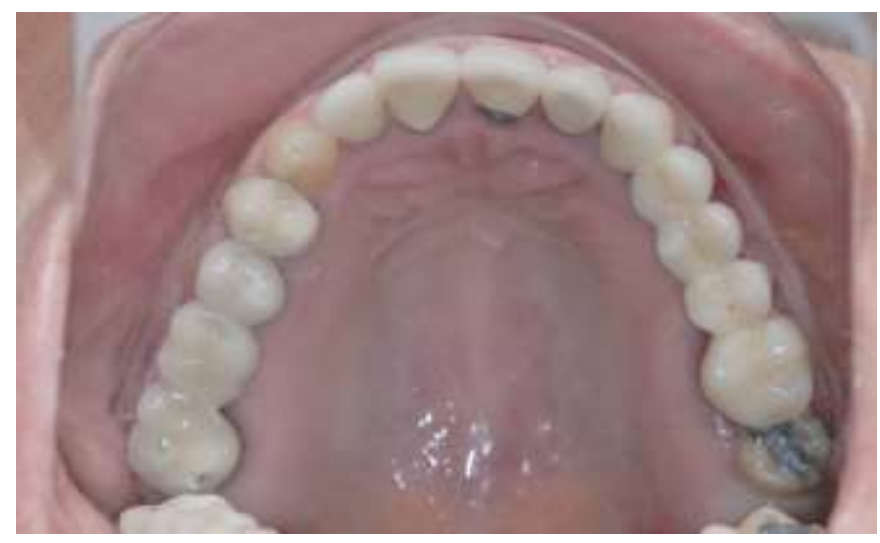

Source: Authors. 
It is consensus in oral rehabilitation that clinical examination alone is not sufficient to establish the diagnosis and to elaborate a treatment plan. Radiographic examination and the fabrication of study models in an articulator are necessary for safe planning of the clinical case. The literature recommends the use of periapical radiography for the teeth chosen as prosthetic pillars (in this case, the pillars that will receive the unitary crowns after implantation), in addition to endodontically treated teeth. Panoramic radiography can be used as an initial imaging method to trace the profile of each patient for radiographic investigation, in addition to providing important data about the edentulous area. However, in the present case, to meet the patient's objective, computed tomography was indicated, which showed a satisfactory bone condition for implant placement in the partially edentulous area.

Figure 3 shows the periapical radiograph in which a radiolucent area with a radiopaque halo suggestive of granuloma or periapical cyst was observed at the apex of tooth 22 . The endodontic treatment of that tooth was classified as in good condition, with the obturation being intact and being performed about $1 \mathrm{~mm}$ below the apical foramen, a procedure considered normal in endodontic therapy. In this case, considering the existence of a periapical lesion in a tooth with satisfactory endodontic treatment and the absence of painful symptoms, two strategies can be proposed: to retrieve the final radiograph obtained on the occasion of endodontic treatment and to compare the stage of the lesion in terms of size and/or radiopacity; or, if such radiograph is not available, to start a program of quarterly clinical follow-up and radiographic examination, comparing the images regarding the same features as cited above. The dentist would thus be able to decide about the need or not and the type of treatment to be performed (follow-up, retreatment, or parendodontic surgery).

Figure 3: Routine periapical radiography showing a radiolucent lesion at the apex of tooth 22.

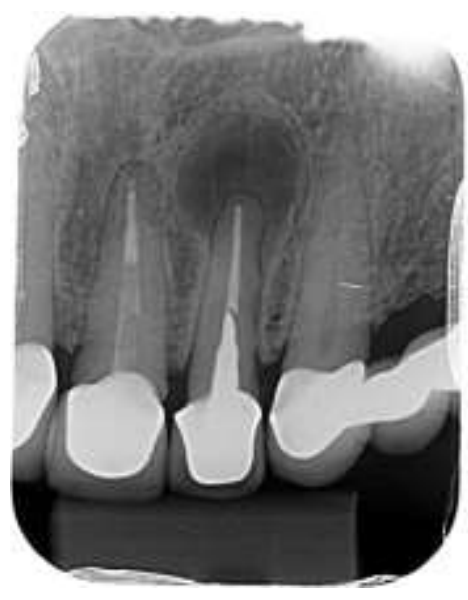

Source: Authors.

Since we did not have access to previous radiographs because the patient was treated by another professional in another state, a CBCT scan was requested for better analysis of the lesion. We found that conventional radiographic analysis alone would lead the professional to make a decision that would be totally inadequate for resolution of the case. Analysis of the parasagittal CBTC sections (Figure 4) radically changed the diagnosis of the condition, especially in terms of the most appropriate clinical management for resolution of the case. 
Figure 4: Detailed analysis of the CBCT sections. Observe the root perforation in the palatine wall of tooth 22.

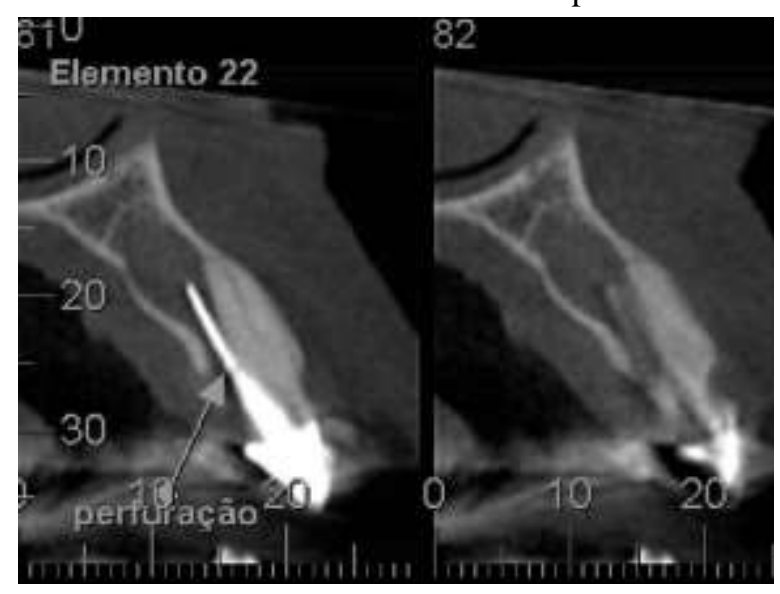

Source: Authors.

Analysis revealed failure on the occasion of endodontic treatment of tooth 22, probably during the instrumentation step, causing a perforation that resulted in an endoperiodontal communication in the palatine wall of the root canal. The radiographic image continued to indicate a granulomatous or cystic lesion, but what appeared to be a periapical condition was now considered a condition of lateral origin, ruling out the hypothesis that the lesion already existed on the occasion of endodontic treatment. Thus, the lesion originated from the dentally caused perforation of the canal and endoperiodontal communication. The final diagnosis was a iatrogenic condition and the clinical hypothesis of a stabilized lesion due to a reduction in size or apical scar was ruled out.

Once the diagnosis of a perforation in the middle third was established, the involved tooth was extracted (Figure 5) and the associated lesion was removed for histopathological analysis (Figure 6). As postoperative medications, $500 \mathrm{mg}$ azithromycin (one tablet per day for 3 days) was administered to prevent infection and oral sodium dipyrone $(500 \mathrm{mg} / 5 \mathrm{~mL} ; 40$ drops every 6 hours for 2 days) for postoperative pain relief, as well as $0.12 \%$ chlorhexidine digluconate (mouth rinses twice a day for 7 days). Since the area was contaminated and the residual bone structure was inadequate, the osseointegrated implant was not immediately placed and it was decided to wait 4-6 months until proper bone repair and maturation.

Figure 5: Photograph obtained immediately after tooth extraction showing the gutta-percha cone outside the root canal.

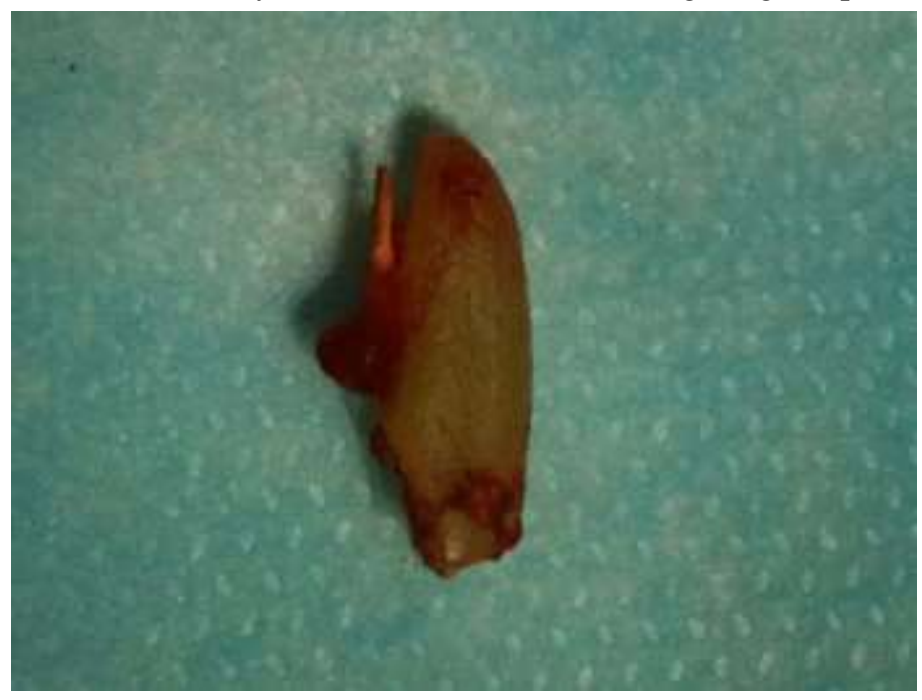

Source: Authors. 
Figure 6: Macroscopic appearance of the lesion.

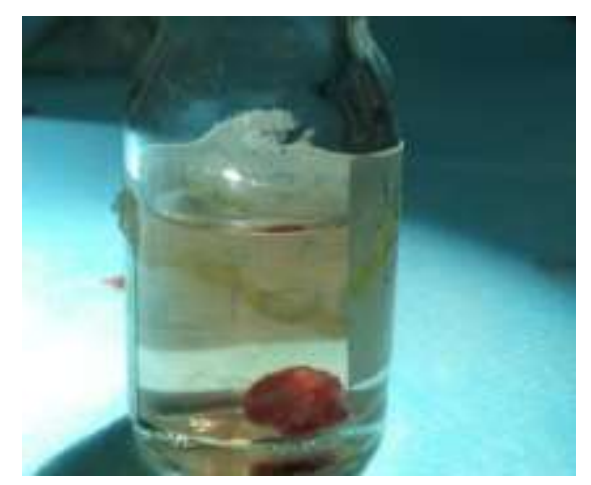

Source: Authors.

The specimen was fixed in $10 \%$ formalin, processed at the Laboratory of Histopathology of UERN, and stained with hematoxylin-eosin. Histopathological analysis led to the diagnosis of a radicular cyst. Non-keratinized stratified pavement epithelium partially lined the cavity of the cyst and there was a vascularized fibrous connective tissue capsule of variable density containing collagen fibers and an intense diffuse mononuclear inflammatory infiltrate (Figures 7 and 8). Abundant negative images of cholesterol crystals were also observed (Figure 9).

Figures 7 and 8: Histological sections showing the cavity partially lined with non-keratinized stratified pavement epithelium. The capsule consists of vascularized fibrous connective tissue.

Figure7

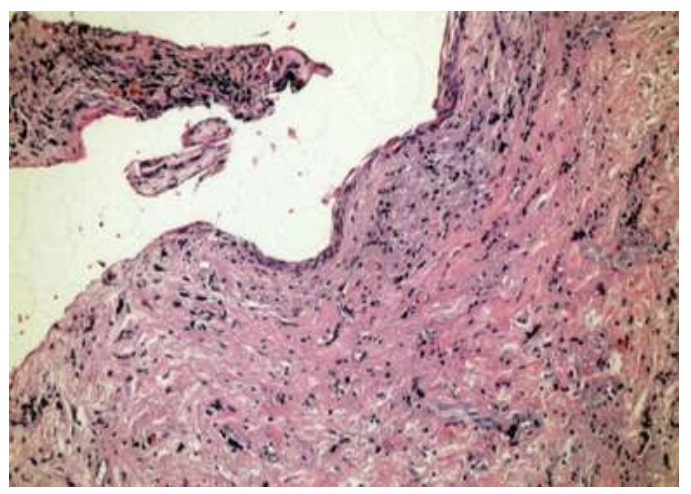

Figure 8

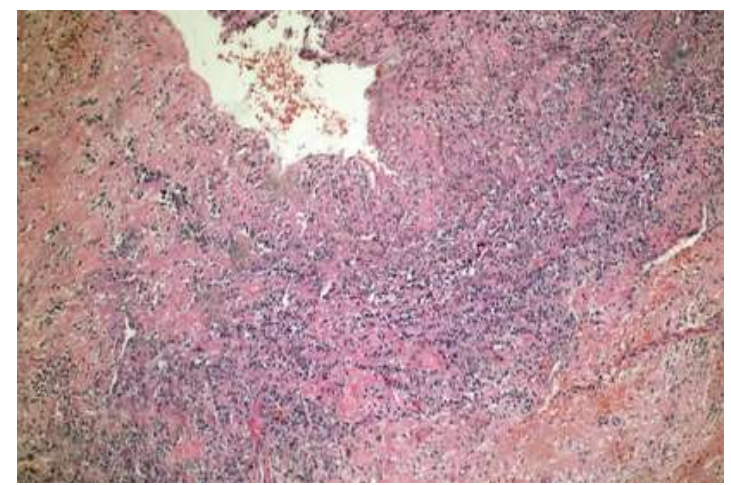

Source: Authors.

Figure 9: Abundant negative images of cholesterol crystals.

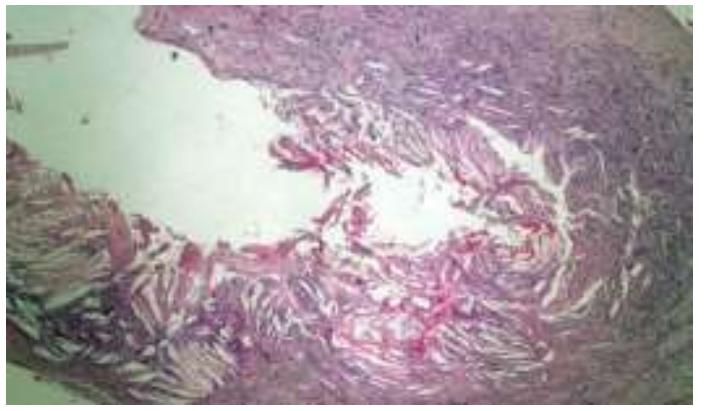

Source: Authors. 


\section{Discussion}

The present study demonstrated the importance of the correct indication of periapical radiography and CBTC to establish the correct diagnosis since, in the case of a misdiagnosis, the treatment of choice for the patient would be unsatisfactory.

Despite the development of new techniques such as digital imaging and ultrasensitive films, conventional radiographs do not overcome the limitations of two-dimensional imaging. The same does not occur with the use of CBCT (Akesson, Håkansson \& Rohlin, 1992; Arai., Tammisalo, Iwai, Hashimoto\& Shinoda, 1999). In addition, this technique eliminates distortions and permits to visualize structures in all three orthogonal planes (three-dimensional imaging) (Ludlow, DaviesLudlow \& Brooks, 2003; Mah, Danforth, Bumann \& Hatcher, 2003). The American Academy of Oral and Maxillofacial Radiology (AAOMR) and the American Association of Endodontists (AAE) issued a declaration that emphasizes the rational indication of CBCT, which should be used only after complete clinical examination, and that the diagnostic benefits of scanning should outweigh the risks of radiation exposure (Scarfe, Levin, Gane \& Farman, 2009). In the area of Endodontics, several benefits of CBCT in diagnosis and treatment have been demonstrated as 3D imaging allows to observe the tooth in different planes of vision. In this respect, CBCT is essential in endodontic retreatment and in the detection of unidentified canals, root fractures, perforations and other conditions by avoiding unnecessary tooth structure removal (Mushtaq, Farooq, Rashid \& Robbani, 2011).

In view of the complexity of the present case, conventional radiography was considered ineffective in solving the endodontic problem and we therefore chose to use CBCT (Tantanapornkul et al, 2007). We emphasize that this imaging method was essential for identifying the iatrogenic nature of the condition. In this case, dental science would indicate quarterly clinical-radiographic follow-up, including possible parendodontic surgery and curettage of the lesion, but no type of endodontic procedure. Conventional radiographic examination (as can be seen in Figure 3) would lead to an inadequate decision to resolve the clinical condition, as demonstrated by the fact that the patient sought a dental service for implant placement and implant-supported dentures, with the consequent indication of CBCT. It should be noted that in the present case the routine imaging method would be periapical radiography to evaluate the quality of the endodontic treatment performed and the integrity of the periapical region. In the present case, the two-dimensional imaging of conventional periapical radiography did not permit visualization of the non-obturated root canal nor the perforation in the lateral wall of the canal and the creation of a false instrumented and obturated canal. This limitation is not observed for CBCT, thus improving detection of the disease of endodontic origin and permitting more effective treatment planning (Durack \& Patel, 2012).

Based on a previous study (Al Fouzan $e t$ al, 2015), careful evaluation by the dental surgeon must be emphasized, who should always use the clinical and complementary arsenal for diagnostic conclusion of each case as a fundamental step in elaborating an adequate treatment plan. However, the lack of three-dimensional data interferes with the establishment of an accurate diagnosis.

One study compared the diagnostic accuracy of CBCT, panoramic radiography and conventional and digital periapical radiography in the diagnosis of perforations. $\mathrm{CBCT}$ was more effective than the other methods in the diagnosis of external root resorption and root fractures. With respect to the diagnosis of root perforations, the authors concluded that CBCT and periapical radiography obtained similar results (Takeshita, Chicarelli \& Iwaki, 2015). This contrasts with the present study in which the perforation was only diagnosed by 3D imaging. Different conclusions were drawn in another study. The authors compared the accuracy of intraoral conventional radiography, photostimulable phosphor radiography, CBCT, and multidetector computed tomography (MDCT) in diagnosing the presence of perforations in endodontically treated teeth, and found no significant differences between methods, except for CBCT and MDCT. The authors concluded that it is not possible 
to diagnose perforations on periapical radiographs, CBCT is the best radiographic technique indicated, and MDCT is not recommended (Shokri, Eskandarloo, Noruzi-Gangachi \& Khajeh, 2015).

In a study comparing the accuracy of high- and low-resolution CBCT for the detection of perforations in endodontically treated lower molars, the authors concluded that the high-resolution mode was more accurate than the lowresolution mode. Nevertheless, both techniques resulted in significant detection of perforations, in agreement with the present findings (Shokri et al, 2018). The sensitivity and specificity of CBCT and of digital periapical radiography in detecting perforations in the mesial root of lower molars have been demonstrated in an in vitro study. Periapical radiography with three different angulations was found to be reliable, but the use of 3D imaging is recommended to detect perforations before root canal obturation (Haghanifar., Moudi, Mesgarani, Bijani \& Abbaszadeh, 2014). Another study analyzed CBCT of endodontically treated teeth and dental implants to identify the most common errors, which were underfilling and thread exposures, respectively (Silva, Alencar., Rocha, Lopes \& Estrela (2012). Taken together, these findings show that operative errors can occur and are risk factors for the prognosis of the tooth or dental implant.

\section{Final Considerations}

In this case report, we highlight the importance of diagnosing root perforations by CBCT since the endodontic perforation related to tooth 22 was diagnosed as para-apical based on the image obtained from one of the sections, demonstrating the need for correct imaging referral by the dentist in order to avoid exposing the patient to undue risk (Jaju \& Jaju, 2015). Despite its slow growth, the size of the lesion tends to increase silently over time, causing variable local damage or suffering exacerbation.

The use of CBCT is extremely important in Dentistry, as it makes it possible:

- to visualize the bone and dental structures in detail;

- establish the correct diagnosis;

- establish the appropriate treatment plan for each case.

\section{References}

Akesson L., Håkansson J. \& Rohlin M. (1992). Comparison of panoramic and intraoral radiography and pocket probing for the measurement of the marginal bone level. J Clin Periodontol. 19: 326-32. https://doi.org/10.1111/j.1600-051X.1992.tb00654.x.

Al fouzan k., et al. (2015). Marginal adaptation of mineral trioxide aggregate (mta) to root dentin surface with orthograde/retrograde application techniques: a microcomputed tomographic analysis. J conserv dent. 18(2):109-13. http://www.jcd.org.in/article.asp?issn=09720707 ; year $=2015 ;$ volume $=18 ;$ issue $=2 ;$ spage $=109 ;$ epage $=113 ;$ aulast $=$ al

Alves, D. F., Gomes, F. B., Sayão, S. M., \& Mourato, A. P. (2005) Tratamento clínico cirúrgico de perfuração do canal radicular com MTA - caso clínico. Int J Dent. 4(1):1-6. http://revodonto.bvsalud.org/pdf/ijd/v9n4/10.pdf

Arai, Y., Tammisalo, E., Iwai, K., Hashimoto, K. \& Shinoda, K. (1999) Development of a compact computed tomographic apparatus for dental use. A Journal of Head and Neck Imaging. 28: 245-8. https://doi.org/10.1038/sj/dmfr/4600448

Baratto Filho F. et al. (2009). Analysis of the internal anatomy of maxillary first molars by using different methods. $J$ Endod. 35(3):337- 42. https://doi.org/10.1016/j.joen.2008.11.022

Bernardes, R. A. et al. (2009). Use of cone-beam volumetric tomography in the diagnosis of root fractures. Oral Surg Oral Med Oral Pathol Oral Radiol Endod. 108:270-7. https://www.oooojournal.net/article/S1079-2104(09)00027-4/fulltext

Bueno, M. R., Estrela, C., Azevedo, B. C., Brugnera Junior, A., \& Azevedo, J. B. (2007). Tomografia computadorizada cone beam: revolução na odontologia. Rev Assoc Paul Cir Dent. 61(5):354-63. http://bases.bireme.br/cgi-bin/wxislind.exe/iah/online/

Durack, C., \& Patel S. (2012). Cone beam computed tomography in endodontics. Braz dent j. 23(3): 179-191. https://www.scielo.br/pdf/bdj/v23n3/a01v23n03.pdf

Haghanifar, S., Moudi, E., Mesgarani, A., Bijani, A., \& Abbaszadeh, N. (2014). A comparative study of cone-beam computed tomography and digital periapical radiography in detecting mandibular molars root perforations. Imag Sci Dent. 44:115-9. https://doi.org/10.5624/isd.2014.44.2.115 
Research, Society and Development, v. 10, n. 2, e25010211320, 2021 (CC BY 4.0) | ISSN 2525-3409 | DOI: http://dx.doi.org/10.33448/rsd-v10i2.11320

Jaju, P. P., \& Jaju, S. P. (2015). Cone-beam computed tomography: Time to move from ALARA to ALADA. Imag Sci Dent. 45:263-5. https://doi.org/10.5624/isd.2015.45.4.263

Ludlow, J. B., Davies-Ludlow, L. E. \& Brooks, S. L. (2003). Dosimetry of two extraoral direct digital imaging devices: NewTom cone beam CT and Orthophos Plus DS panoramic unit. A Journal of Head and Neck Imaging. 32: 229-34. https://doi.org/10.1259/dmfr/26310390

Mah, J. K., Danforth, R. A., Bumann, A., \& Hatcher D. (2003). Radiation absorbed in maxillofacial imaging with a new dental computed tomography device. Oral Surg Oral Med Oral Pathol Oral Radiol Endod. 96: 508-13. https://doi.org/10.1016/S1079-2104(03)00350-0

Moudi E. et al. (2014). Assessment of vertical root fracture using cone-beam computed tomography. Imaging Sci Dent. 44:37-41. https://isdent.org/DOIx.php?id=10.5624/isd.2014.44.1.37

Mushtaq, M., Farooq, R., Rashid, A. \& Robbani, I. (2011). Avaliação tomográfica computorizada espiral e manejo endodôntico, J. Conserv. Dent. 14(2): 196198.

Pereira, A. S., et al. (2018). Metodologia da pesquisa científica. UFSM. https://repositorio.ufsm.br/bitstream/handle/1/15824/Lic_Computacao_MetodologiaPesquisa-Cientifica.pdf?sequence $=1$.

Scarfe, W. C. (2011). Use of cone-beam computed tomography in endodontics. Oral Surg Oral Med Oral Pathol Oral Radiol Endod. 111(2):234-7. https://doi.org/10.1016/j.tripleo.2010.11.012

Scarfe, W. C., Levin, M. D., Gane D., \& Farman, A. G. (2009). Use of Cone Beam Computed Tomography in Endodontics. Int J Dent. 1- 20. https://www.ncbi.nlm.nih.gov/pmc/articles/PMC2850139/pdf/IJD2009-634567.pdf

Shokri, A., Eskandarloo, A., Noruzi-Gangachi, M. \& Khajeh, S. (2015). Detection of root perforations using conventional and digital intraoral radiography, multidetector computed tomography and cone beam computed tomography. Restorative Dentistry \& Endodontics. 40(1):58-67.

https://doi.org/10.5395/rde.2015.40.1.58

Shokri A. et al. (2018). Diagnostic accuracy of cone-beam computed tomography scans with high- and low-resolution modes for the detection of root perforations. maging Science in Dentistry. 48: 11-9. https://doi.org/10.5624/isd.2018.48.1.11

Silva, J.A., Alencar, A. H. G., Rocha, S. S., Lopes, L. G., \& Estrela, C. (2012). Three-dimensional image contribution for evaluation of operative procedural errors in endodontic therapy and dental implants. Braz Dent J. 23(2): 127-134. https://doi.org/10.1590/S0103-64402012000200007

Takeshita, W. M., Chicarelli, M. \& Iwaki, L. C. (2015). Comparison of diagnostic accuracy of root perforation, external resorption and fractures using conebeam computed tomography, panoramic radiography and conventional and digital periapical radiography. Ind J Dent Res. 26:619-26. https://pubmed.ncbi.nlm.nih.gov/26888242/

Tantanapornkul, W., et al. (2007). A comparative study of cone-beam computed tomography and conventional panoramic radiography in assessing the topographic relationship between the mandibular canal and impacted third molars. Oral surg oral med oral pathol oral radiol endod. 103(2):253-9. https://doi.org/10.1016/j.tripleo.2006.06.060

Tsesis I. \& Fuss Z. (2006). Diagnosis and treatment of accidental root perforations. Endod Topics. 13: 95-107. https://doi.org/10.1111/j.16011546.2006.00213.x 